\title{
Impact of Macro - Economic Factors on Indian Stock Market- A Research of BSE Sectoral Indices
}

\author{
R. Venkatamuni Reddy, Raghavendra Nayak, Nagendra S, Ashwith
}

\begin{abstract}
Macro-Economic factors plays a major role in decision making. Evaluation of macroeconomic environment is required to examine the behaviour of stock prices, which further influences the investor's investment behaviour. Even though some macro-economic factors are not directly related to the company or industry, but those factors has an impact on stock prices, further economic activity in the domestic and global level has its own impact on stock market. When economy of the country grows hastily, it leads to faster growth in the industry and vice versa. Financial market plays a central role in the performance of financial system of an economy. Stock market is a market where securities of listed companies are exchanged between different investors, it is very responsive market which, gives a stage to investors to invest their money in various securities. Market indices are the tools to measure the performance of various securities of stock market and Investors make use of those market indices to analyse performance of those industries in which, they prefer to invest. This study takes into account six macro-economic factors (Crude oil Price, Gold Price, Silver Price, Exchange Rate, Inflation and Interest Rate) to study \& analyse the impact of these variables on selected sectoral indices at BSE, SENSEX, S\&P BSE $B A N K E X, S \& P$ BSE Oil and Gas, S\&P BSE Capital Goods, S\&P BSE Consumer Durables, S\&P BSE Reality, S\&P BSE PSU and $S \& P$ BSE Power. The study shows that gold price, exchange rate, consumer price index and interest rate are positively correlated with four indices but crude oil price and silver price have positively correlated with 3 indices. So from the result it is clear that investor need to take of all the variables for their investment decision and the investment banker also take care of these indicators before giving suggestion to their clients
\end{abstract}

Index Terms: Macro -economic, Stock Market, Market Indices,

SENSEX, BSE, Inflation, Interest rate

\section{INTRODUCTION}

Stock exchanges are the marketplace for securities of Government and semi Government bodies or other public bodies as also for shares and debentures issued by the joint stock companies. In the stock market, exchanges of shares

Revised Manuscript Received on July 5, 2019.

R. Venkatamuni Reddy, Professor, Department of Commerce, Manipal Academy of Higher Education, Manipal, Karnataka

Raghavendra Nayak, Assistant Professor-Senior Scale, Department of Commerce,Manipal Academy of Higher Education, Manipal, Karnataka

Dr. Nagendra S, Associate Professor, Department of Business Administration, Alvas Institute of Engineering and Technology, Mijar-Moodbidri-574225 D.K. Karnataka Email ID: nagendraskyfall@gmail.com

Mr. Ashwith, Assistant Manager, Trade Finance Department, Kotak Mahindra Bank Limited, Trade Processing Centre, Kotak Infinity, $6^{\text {th }}$ Floor, Zone 4, A.K. Vaidya Marg, Malad (E) Mumbai -400097 Email ID: ashwithsuvarna2@gmail.com takes place in a free competition, over the counter sales or purchase will be there for government securities. The bargains that are fixed in the trading circle by the member of stock exchanges at the fairest prices determined by the fundamental laws of supply and demand. Securities market is financial market where equities, shares, debentures; bonds etc., are bought and sold. On daily basis stocks are exchanged and traded in different stock markets around the Globe. The liquidity they fetch is a very important component of economic growth. Share market is an open market were the buying and selling of companies stock at an agreed price will takes place.

\section{A.Theoretical Background of the Study}

Stock market is a very sensitive market, Stock prices are depending on many factors. Stock market play very crucial role in the finance sector of economy. Economic activities in the national and international level have impact on the market movement. Analysis of a security involves fundamental and technical analysis. Fundamental analysis consists of economic analysis, industry analysis and company analysis. The decision of investors depends on this analysis. Economic analysis consist various factors. Stock prices fluctuation depends on various factors. For better understanding they are divided into two major parts, Micro Economic and Macro Economic factors.

Micro Economic factors are those which can be controlled for certain level and they are within the scope. Macro-economic factors are the external and are cannot be controlled easily. They directly or indirectly affects the share prices, so it is important to study the macro- economic factors Macro-economic factors are independent variables but these factors influence the company's decisions making. Some of the macro factors: Technological changes, Natural factors, Inflation rate, Exchange rates, Interest rates, Gross Domestic Product (GDP), Political and social conditions, Tax structure, Savings and investment Foreign institutional investment Budget etc.

\section{B. Study Considers Six Macro Economic Factors}

Macro economic factors have positive as well as negative impact on the performance of share prices. Macro economic factors are highly independent factors, it is difficult to study different affects of each variable on stock market movement.

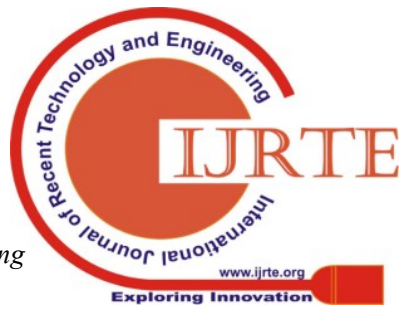


For that reason and better understanding this research is conducted to study the impact of six macro-economic factors on the performance stock market, they are, Inflation, Interest rate, Gold price, Silver price, Exchange rate and Crude oil price

\section{LITERATURE REVIEW}

The investigation has been led by such significant number of researchers all around the globe. They considered distinctive full scale financial components and given diverse conclusions and recommendations. Some of them are investigated as follows.

Tripathi L K, Parashar Arpan and Jaiswal Swati (2014) directed an examination on "Effect of macroeconomic factors on sectoral files in India". They considered 5 macroeconomic factors, for example, trade rates, remote institutional ventures, unrefined petroleum costs, current record adjust and outside trade saves. Analyzed the effect of these variables on five sectoral files at national stock exchange (CNX auto, CNX vitality, CNX IT, CNX FMCG and CNX bank). Results uncover that with all large scale financial factors Foreign Institutional Investments influences all sectoral records and rest of macroeconomic factors specifically influence diverse sectoral files in India.

Patel Samveg (2012) conveyed an exploration on "The impact of macroeconomic determinants on the execution of the Indian securities exchange". The month to month information from January 1991to December 2011 has been considered by him. He took 8 large scale monetary factors, for example, loan fee, cash supply, conversion standard, gold rate, silver rate, expansion oil costs and record mechanical creation. He inspected and examined the impact of these components on two securities exchange records called, SENSEX and CNX clever. comes about says that loan fee is I(0); SENSEX, Nifty, conversion scale, gold value silver value, list of modern generation, and oil costs are I(2). As per his figuring there is a connection between large scale financial variables and sectoral records.

Singh Pooja (2014) conveyed an exploration on "Indian securities exchange a full scale monetary factors in current situation". He considered period from January 2011 to December 2012 for his investigation. He utilized 10 factors, for example, cash supply, loan fee, conversion scale, oil costs, gold costs, silver costs, exchange deficiency, and list of modern creation, remote institutional ventures and discount value file. He inspected these components on two securities exchange files say, BSE Sensex and CNX Nifty. The investigation demonstrates that objecives of the examination has been met.

Kotha Kumar Kiran and Sahu Bhawna (2016) made an exploration on "Large scale financial variables and Indian securities exchange: investigating long and short run connections". Information was gathered from July 2001 to July 2015 for the investigation. They considered 4 full scale financial variables like swapping scale, discount value list, t-charge rates and $\mathrm{M} 3$. The investigation demonstrates the nearness of long run connection between BSE SENSEX and select 4 full scale financial components.

K Gurloveleen and BS Bhaitia (2015) led examine on "An effect of macroeconomic factors on the working of Indian securities exchange: An investigation of assembling firms of BSE 500". They considered 10 full scale financial factors say, expansive cash, call cash rate, unrefined petroleum costs, swapping scale, net monetary shortage, remote trade saves, outside institutional speculators, record of mechanical generation, swelling rate and exchange adjust. The outcome demonstrates that there was no relationship found among the chose factors files.

Ouma Nduga Wycliffe and Muriu Peter (2014) conveyed an exploration on "Effect of macroeconomic factors on securities exchange return in Kenya". The investigation utilized information from 2003 to 2013. They utilized arbitrage estimating hypothesis and capital resource evaluating model (CAPM) to distinguish the effect of macroeconomic factors on stock returns. As per the discoveries cash supply, loan cost and swapping scale have affect on the stock exchange returns in Kenya.

Barakat Ramadan Mahmoud, Elgazzar H Sara and Hanafy M Khaled (2015) produced examine on "Effect of macroeconomic factors on securities exchanges: Evidence from developing markets". Information gathered from January 1998 to January 2014 for the information examination. They thought about full scale monetary factors in two developing economies (Egypt and Tunisia). An outcome demonstrates that, there is a typical relationship in Egypt between showcase records and full scale financial elements. Similar conveys for Tunisia aside from CPI (Consumer Price Index), which had no importance with the share trading system.

Buddy Karam and Mittal Ruhee (2011) conveyed inquire about on "Effect of macroeconomic pointers on Indian capital markets". Goal of the examination is to explore the long run noteworthiness between the Indian securities exchanges and full scale factors say, financing costs, expansion rates, trade rates and gross household reserve funds of Indian economy. Information utilized from December 2008 to January 1995 for the investigation. Results demonstrate that there is no connection between large scale financial variables and sectoral record.

Khan Nauman Muhammad and Zaman Sharif (2012) completed an examination on "Effect of macroeconomic factors on stock costs: Empirical confirmation from Karachi Stock Exchange (KSE) Pakistan". Accumulated information from 1998 to 2009. 
They considered 7 macroeconomic markers like, swapping scale, customer value list, remote direct investment (FDI), oil costs, trades, Gross Domestic Product (GDP) and cash supply. As per the discoveries total national output and trade rates positively influences the stock costs.

\section{OBJECTIVES OF THE STUDY}

The main objective of this study is to analyse the impact of macro-economic factors on Indian stock market. They are To examine the relationship between Indian Stock Market and selected macro - economic variables.

To identify the impact of changes in the selected macro-economic factors on the particular sectoral indices at BSE.

To assess the future movement of factorial indices in Indian stock market.

\section{RESEARCH METHODOLOGY}

This study considers data from January 2008 to December 2017. The study considers 6 macro-economic factors and considers the descriptive statistical tools like maximum value, minimum value, mean, Kurtosis and skewness and other techniques like expected return, average return, standard deviation, correlation and multiple regression are used in order to discover the relation between the macro-economic factors and the performance of the stock market. For fulfilling the objective of the study we collected the information related to primary and secondary data.

Table 1: Dependent and independent variables

\begin{tabular}{|c|l|}
\hline \multirow{2}{*}{$\begin{array}{c}\text { Dependent } \\
\text { variable }\end{array}$} & BSE Crude Oil Price, BSE Capital goods, \\
\cline { 2 - 2 } & BSE Sensex, BSE Bankex, BSE Reality, \\
\cline { 2 - 2 } & $\begin{array}{l}\text { BSE Consumer Durables, BSE PSU and } \\
\text { BSE }\end{array}$ \\
\cline { 2 - 2 } & Power \\
\hline $\begin{array}{c}\text { Independent } \\
\text { variable }\end{array}$ & $\begin{array}{l}\text { Crude Oil Price, Exchange Rate, Gold } \\
\text { Price, }\end{array}$ \\
\cline { 2 - 2 } & Silver Price, Inflation and Interest Rate \\
\hline
\end{tabular}

Table 2: Description of the data used in the study

\begin{tabular}{|l|l|l|}
\hline $\begin{array}{c}\text { Name of the } \\
\text { variable }\end{array}$ & \multicolumn{1}{|c|}{ Symbol used } & \multicolumn{1}{c|}{ Proxy used } \\
\hline $\begin{array}{l}\text { Crude Oil } \\
\text { Price }\end{array}$ & COP & $\begin{array}{l}\text { International } \\
\text { Crude Oil Price }\end{array}$ \\
\hline $\begin{array}{l}\text { Exchange } \\
\text { Rate }\end{array}$ & ER & $\begin{array}{l}\text { Monthly Average } \\
\text { Rupees } \\
\text { Per Unit Of US\$ }\end{array}$ \\
\hline Gold Price & GP & OUNCE \\
\hline Silver Price & SP & OUNCE \\
\hline Inflation & IF & $\begin{array}{l}\text { Consumer Price } \\
\text { Index }\end{array}$ \\
\hline Interest Rate & IR & $\begin{array}{l}\text { Weighted, } \\
\text { Average } \\
\text { Call Money Rate }\end{array}$ \\
\hline & S\&P BSE Crude Oil & $\begin{array}{l}\text { All Stock } \\
\text { Indices, } \\
\text { Indices }\end{array}$ \\
& Price & Monthly., \\
\hline
\end{tabular}

\begin{tabular}{|l|l|l|}
\hline & $\begin{array}{l}\text { S\&P BSE Capital } \\
\text { Goods }\end{array}$ & Closing Price \\
\hline & S\&P BSE SENSEX & \\
\hline & S\&PBSE BANKEX & \\
\hline & S\&P BSE Reality & \\
\hline & $\begin{array}{l}\text { S\&P BSE Consumer } \\
\text { Durables }\end{array}$ & \\
\hline & S\&P BSE PSU & \\
\hline & S\&P BSE Power & \\
\hline
\end{tabular}

Hypothesis: The Hypothesis formulated in this study is as below:

$\mathrm{H} 0=$ there is no significant relationship between the selected macro factors and stock indices of India

$\mathrm{H} 1$ = there is significant relationship between the selected macro factors and stock indices of India

\section{DAta AnAlysis ANd Interpretation}

The study attempted to analyze the data collected to meet the objectives of the study. A descriptive analysis is made of dependent variables as well as independent variables. Monthly data are collected for the purpose of the study and factor wise analysis is made. This analysis conducted to check how each selected macro-economic variables impacts on the sectoral indices. The returns are calculated on the basis of monthly index prices, expected return and abnormal returns are calculated and used for the analysis. The correlation analysis is also done, to find out how dependent and independent variables are correlated. Multiple regression analysis is also used for this study.

Table 3: Correlation Coefficient between macro-economic variables and SENSEX study

\begin{tabular}{|l|l|l|l|l|l|l|}
\hline & COP & GP & SP & ER & CPI & IR \\
\hline SENSEX & -0.4696 & 0.1271 & -0.1776 & 0.7834 & 0.8616 & 0.2832 \\
\hline
\end{tabular}

Source: Author's compilation. Software used: SPSS

Table 3 indicates the correlation between BSE SENSEX and the 6 macro-economic variables. Correlation results show that the BSE SENSEX have positively correlated with exchange rate, consumer price index, gold price and interest rate. But it has significantly negative relationship with crude oil price and silver price.

Level of correlation is high between BSE SENSEX and CONSUMER PRICE INDEX [0.86]. This explains that, there is inverse relationship between SENSEX and inflation rate. When inflation rate increases, SENSEX decreases. Low level of significant exists between SENSEX and CRUDE OIL PRICE. 
Table 4: Correlation Coefficient between Macro

Economic variables and BSE Oil and Gas

\begin{tabular}{|l|l|l|l|l|l|l|}
\hline & COP & GP & SP & ER & CPI & IR \\
\hline $\begin{array}{l}\text { BSE oil } \\
\text { and gas }\end{array}$ & -0.2467 & -0.0585 & -0.1842 & 0.3088 & 0.4655 & 0.0971 \\
\hline
\end{tabular}

Source: Author's compilation. Software used: SPSS

BSE Oil and Gas have positive relationship with exchange rate, consumer price index and interest rate. It has negative relationship with crude oil price, gold price and silver price. If variables having negative correlation, increases, then oil and gas price will decrease.

Table 5: Correlation Coefficient between MacroEconomic Variable and BSE Capital Goods

\begin{tabular}{|l|l|l|l|l|l|l|}
\hline & COP & GP & SP & ER & CPI & IR \\
\hline $\begin{array}{l}\text { BSE } \\
\text { Capital } \\
\text { goods }\end{array}$ & -0.3650 & -0.1128 & -0.2080 & 0.2798 & 0.4029 & 0.1078 \\
\hline
\end{tabular}

\section{Source: Author's compilation}

Exchange rate, consumer price index and interest rate have positive correlation with BSE capital goods. Crude oil price, gold price, silver price have inverse relationship with the index.

Table 6. Correlation Coefficient between BSE BANKEX and Dependent Variables

\begin{tabular}{|l|l|l|l|l|l|l|}
\hline & COP & GP & SP & ER & CPI & IR \\
\hline BSE & & & & & & \\
BANKEX & -0.5394 & 0.1674 & -0.1481 & 0.7712 & 0.8571 & 0.2118 \\
\hline
\end{tabular}

\section{Source: Author's compilation}

Level of correlation is negative between BSE BANKEX and crude oil price and silver price but has positive relation with other 4 variables.

Table 7. Correlation Coefficient between Dependent Variables and BSE Reality

\begin{tabular}{|l|l|l|l|l|l|l|}
\hline & COP & GP & SP & ER & CPI & IR \\
\hline $\begin{array}{l}\text { BSE } \\
\text { Reality }\end{array}$ & 0.3485 & -0.4234 & -0.1343 & -0.6597 & -0.5886 & -0.0007 \\
\hline
\end{tabular}

\section{Source: Author's compilation}

BSE Reality has positive correlation with crude oil price and have negative correlation with all other variables.

Table 8: Correlation Coefficient between dependent variables and BSE consumer durables

\begin{tabular}{|l|l|l|l|l|l|l|}
\hline & COP & GP & SP & ER & CPI & IR \\
\hline BSE & -0.5215 & 0.1865 & -0.1243 & 0.7495 & 0.8478 & 0.1637 \\
$\begin{array}{l}\text { Consumer } \\
\text { Durables }\end{array}$ & & & & & & \\
\hline
\end{tabular}

\section{Source: Author's compilation}

In case of BSE Consumer durables, it has negative correlation with crude oil price and silver price. But has high correlation with remaining items.
Table 9: Correlation Coefficient between BSE PSU and dependent variables

\begin{tabular}{|l|l|l|l|l|l|l|}
\hline & COP & GP & SP & ER & CPI & IR \\
\hline BSE PSU & & & & & & \\
& -0.0159 & 0.1254 & 0.1715 & -0.2447 & -0.0489 & -0.2567 \\
\hline
\end{tabular}

Source: Author' compilation

Gold price and silver price had positively correlated with BSE PSU. However, it had negatively correlated with other variables.

Table 10: Correlation Coefficient between dependent variable and BSE Power

\begin{tabular}{|l|l|l|l|l|l|l|}
\hline & COP & GP & SP & ER & CPI & IR \\
\hline BSE & & & & & & \\
Power & 0.1683 & -0.2606 & 0.0036 & -0.6661 & -0.5533 & -0.2222 \\
\hline
\end{tabular}

\section{Source: Author's compilation}

BSE Power have inverse relation with all other variables except crude oil price and silver price as they have positive relation with index.

Table 11: Regression statistics results

\begin{tabular}{|l|l|l|l|l|l|l|}
\hline & & & $\begin{array}{l}\text { Coeffici } \\
\text { ents }\end{array}$ & $\begin{array}{l}\text { Standar } \\
\text { d Error }\end{array}$ & t Stat & P-value \\
\hline $\begin{array}{l}\text { Multipl } \\
\text { e R }\end{array}$ & 0.88721 & $\begin{array}{l}\text { Intercep } \\
\mathrm{t}\end{array}$ & -99428 & 10190.1 & -9.7573 & $\begin{array}{l}1.11 \mathrm{E}-1 \\
6\end{array}$ \\
\hline $\begin{array}{l}\mathrm{R} \\
\text { Square }\end{array}$ & 0.78714 & $\mathrm{COP}$ & -38.55 & 16.7161 & -2.3062 & $\begin{array}{l}0.02292 \\
35\end{array}$ \\
\hline $\begin{array}{l}\text { Adjust } \\
\text { ed R } \\
\text { Square }\end{array}$ & 0.77584 & GP & -0.9809 & 2.91975 & -0.3359 & $\begin{array}{l}0.73753 \\
56\end{array}$ \\
\hline $\begin{array}{l}\text { Standa } \\
\text { rd } \\
\text { Error }\end{array}$ & 2834.84 & SP & -108.34 & 112.885 & -0.9597 & $\begin{array}{l}0.33925 \\
93\end{array}$ \\
\hline $\begin{array}{l}\text { Observ } \\
\text { ations }\end{array}$ & 120 & ER & -168.51 & 91.2941 & -1.8458 & $\begin{array}{l}0.06753 \\
45\end{array}$ \\
\hline & CPI & 599.455 & 64.3869 & 9.3102 & $\begin{array}{l}1.21 \mathrm{E}-1 \\
5\end{array}$ \\
\hline
\end{tabular}

Source: Author's compilation

SENSEX $=-99428.067-168.51335 * \mathrm{ER}+599.455426 * \mathrm{IF}$

$-38.550478 * \mathrm{COP}-0.980874 * \mathrm{GP}-108.33502 * \mathrm{SP}$

$-166.94995 *$ IR

Table 11 reveals the result of multivariate regression analysis. This analysis is conducted to check the impact of correlation of independent variables on single dependent variable (SENSEX). Exchange rate, inflation rate, oil prices, gold price, silver price and interest rate is considered to check the impact of these factors on BSE SENSEX.

The multiple regressions are 0.887 , which reveals that correlation between independent variables and dependent variables that is SENSEX is closer to absolutely positive. $\mathrm{R}$ Square $78.71 \%$ which indicates that independent variables are related to each other when dependent variable (BSE SENSEX) is studied. 
It says that $78.71 \%$ of the difference in SENSEX is determined by the independent variables. The variables which are other than the macro-economic factors, determines only $21.29 \%$ of variation in SENSEX.

The results of the regression:

Inflation has extremely positive and major impact on SENSEX, Interest rate has highly negative but significant impact on SENSEX, Silver price has good positive impact on SENSEX, Exchange rate and crude oil prices and gold prices having negative impact on BSE index. From the above analysis, it is clear that all the independent variables do have impact on the dependent variable. Therefore, null hypothesis is rejected and alternative hypothesis is accepted.

\section{Findings, Suggestions AND CONCLUSIONS}

In case of descriptive analysis of dependent variables, the measurement of Skewness showed that 3 variables are negatively skewed and rest 3 are positively skewed.

The Kurtosis measure shows positive tail for 2 variables (silver price and interest rate), and all 4 has negatively tailed when we find out descriptive analysis. When measured, crude oil price has minimum points in January 2016, hit maximum in June 2008 and average points of Crude Oil Price for 10 years is 76.80, Gold Price have minimum in October 2008 and it is Maximum in August 2011.average points is 1266.93. Silver Price is minimum in 2008 and maximum in April 2011. 20.93 is the Average price.

Exchange rate was Maximum in November 2016 and is Minimum in January 2008. Average price is 55.43. Inflation is minimum in January 2008 likewise they are maximum in April 2017. Average point is 229.45. Interest rate has minimum point in October 2008 and maximum in June 2008. 6.96 is the average interest rate. The descriptive analysis of indices shows the measurement of Kurtosis that 5 BSE indices are negatively tailed and 3 indices (BSE oil and gas, reality and consumer durables) are positively tailed. In case of descriptive analysis, the measurement of Skewness proved that 2 selective indices are positively skewed and remaining 6 negatively skewed. Oil and gas has minimum in November 2008 but it is maximum in October 2017. It has the mean of 9879.29. Capital goods is low in February 2009 and high in December 2017. And mean is 12957.84 SENSEX is minimum in February 2009 and maximum in December 2017. Average is 21145.66. BANKEX is minimum in February 2009 and maximum in December 2017. Mean is 14778.41. Reality is minimum in February 2016 and maximum in January 2008. Average is 2378.49 Consumer durable is low in October 2008 and high in December 2017. Average 7893.47. BSE PSU was minimum in October 2008 and maximum was in September 2010. Mean is 7550.21. Power has minimum points in August 2013 and maximum points in January 2008. Average is 2253.29. Crude oil price volatility in return was minimum in BSE SENSEX is 6.11 which shows that inflation has not affected largely to this Index as it is well organized, whereas BSE Reality had very high volatility in Return, 21.74 wish shows that Crude Oil Price as affected more to the metal industry.

Gold Price BSE SENSEX had low fluctuation in AAR 6.42, which shows that it is well organized and fluctuations in Gold
Price less to BSE Reality had maximum volatility in return of 15.003 which shows that gold price is well organized, though there is changes in gold price it has not affected largely to this industry. Silver price, volatility in return is minimum in BSE SENSEX, 6.20 which shows that this industry is well organized. Volatility in return is maximum in BSE Reality 14.64. Exchange rate SENSEX has low volatility in AAR 5.11 and maximum in BSE Reality 12.14 it clears that stock market and silver prices are interrelated. Inflation Rate volatility in return is low in BSE SENSEX, 6.46 BSE Reality maximum volatility in return 15.08. In overall BSE SENSEX has volatility 6.29; around oil price BSE SENSEX has major impact around its factors. Interest rate BSE SENSEX has 6.09 fluctuations in AAR which is minimum one; it proves that exchange rate has low effect on BSE SENSEX. Volatility in returns is in BSE REALITY 15.52 which shows that Capital Goods industry has a major impact of fluctuation around dollar exchange rate. When correlation analysis was carried out it is found SENSEX is positively correlated with 4 factors which mean that SENSEX is affected by variations in these factors. SENSEX is negatively correlated with crude oil price and Silver price. SENSEX is highly correlated with inflation, foreign exchange rate and foreign trade, whereas interest rate has low correlation with SENSEX remaining other factors lies between these correlated factors. BSE Oil and Gas has positively correlated with crude oil price, gold price, and silver price was negatively correlated with exchange rate, inflation, interest rate. Exchange rate, consumer price index and interest rate have positive correlation with BSE capital goods. Crude oil price, gold price, silver price have inverse relationship with the index. Level of correlation is low between BSE BANKEX and crude oil price and silver Price but has positive relation with other 4 variables. BSE Reality has positive correlation with crude oil price and have negative correlation with all other variables. In case of BSE Consumer durables, it has low correlation with crude oil price and Silver price. But has high correlation with remaining items. Gold price and silver price had positively correlated with BSE PSU. However it had negatively correlated with other data. BSE Power has inverse relation with all other variables except crude oil price and silver Price as they have positive relation with index.

The results of multivariate analysis are:

Multiple regression equation:

SENSEX $=-99428.067-168.51335 * \mathrm{ER}+599.455426 * \mathrm{IF}-$ $38.550478 *$ COP $-0.980874 * \mathrm{GP}-108.33502 * \mathrm{SP}$

$-166.94995 * I R$

It is identified that all the selected macro-economic factors affect the selected BSE sectoral indices. Therefore, null hypothesis is rejected and alternative hypothesis is accepted.

\section{Suggestions}

Indian stock market is affected by both macro factors as well as micro factors. 
Out of these, researcher conducted study on macro-economic factors namely, Crude Oil Price, Gold Price, Silver Price, Exchange Rate, Inflation, and Interest Rate.

To meet the objectives, researcher conducted different statistical techniques and constructed hypothesis. Results say that all 6 macro-economic factors have an impact on Indian stock market. So an objective of the study has met. Investors should give equal importance to each macro-economic factors while investing in stock market. It is suggested that to do a research by including micro factors along with macro-economic variables. It is suggested that the government has to change the monitory, fiscal policies favouring the economy. By looking at the result of this research, it is suggested that inflation rate, interest rate and crude oil prices impacts more on Indian stock market. So with other factors.

\section{CONCLUSION}

This study has explored the relation between Indian stock market and selected macro-economic factors by conducting important analysis which provides positive and negative relation. The study has been conducted by considering data from January 2008 to December 2017. The result helped in identifying the relation between macro-economic factors and BSE Indices which are selected for the study. The study shows that gold price, exchange rate, consumer price index and interest rate are positively correlated with four indices but crude oil price and silver price have positively correlated with 3 indices. So from the result it is clear that investor need to take of all the variables for their investment decision and the investment banker also take care of these indicators before giving suggestion to their clients.

\section{REFERENCES}

1. Pandian punithavathy, security analysis and portfolio management, vikas publishing house pvt ltd, 2009

2. Avadhani V.A, security analysis and portfolio management, Himalaya publishing house, 10th edition, 2010.

3. Dwivedi DN, macroeconomics, tata McGraw-Hill publishing company limited, second edition, 2005.

4. Natarajan $\mathrm{k}$, gordon $\mathrm{E}$, financial markets and services, himalaya publishing house, 6th edition, 2010.

5. Kothari CR and Garg Gaurav, research methodology methods and techiniques, new age international $(\mathrm{P})$ limited, publishers, third edition, 2014.

6. Patel Samveg, "The effect of macroeconomic determinants on the performance of the Indian stock market", NMIMS management review, volume 22, 2012.

7. Singh Pooja,"Indian stock market an macro-economic factors in current scenario", international journal of reasearch in business management, volume 2, issue 11, 2014, pp 43-54.

8. Kotha Kumar Kiran and Sahu Bhawna, "Macro economic factors and international journals of economics and finance issues, volume 6 , issues 3, 2016.

9. K Gurloveleen and BS Bhaitia, "An impact of macroeconomic variables on the functioning of Indian stock market: A study of manufacturing firms of BSE 500", journal stock and forex trading, volume 6, issue 1, 2015.

\section{Webliography:}

1. http;//www.adithyabirlamoney.com/about-us/company profile\&grqid=klgi4A5R\&hl=en-IN

2. http://data.gov.in/catalog/all-india-consumer-price-index-ruralurban

3. http://in.investing.com/commodities/crude-oil-historical-data investor should give more importance to these factors along Indian stock market: exploring long and short run relationships",

4. http://in.investing.com/commodities/silver-historical-data

5. http://in.investing.com/commodities/gold-historical-data

6. http://portal.indianfoline.com/datamonitor/financial-market-monthly/m oney-market/weighted-average-call-money-rates.aspx

7. http://www.investopedia.com/articles/basics/04/050704.asp

\section{AUTHORS PROFILE}

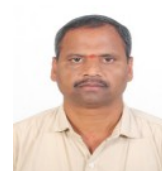

Dr. R. Venkatamuni Reddy has done his Post Graduation and Doctoral Degree in the department of Econometrics, SVUniversity, Tirupati. His experience in the teaching includes Research Methodology, Business Statistics, Quantitative Techniques, Operations Research, Managerial Economics, Mathematical Economics, Econometrics and Data Analysis Methods. Apart from teaching worked extensively with Econometrics, Statistical and Financial Market Packages SPSS, STATA and SAS with large set of data National Sample Survey (NSS), National Family Health Survey (NFHS). Though trained as a researcher, he has published 25 research papers (at national and international levels), presented 20 research papers (seminars/conferences), authored 4 textbooks and participated and Organized as a Convener more than 20 national seminars/FDPs/workshops/International conferences. He is a recognized guide Birla Institute of Technology-Mesra and presently guiding one $\mathrm{PhD}$ Scholars and Awarded One PhD. He is also member/life member various reputed bodies nationally and internationally. He was also associated with Indira Gandhi Institute of Development Research (IGIDR) -Mumbai (2002-2006) as a Research Associate, Research Officer at International Institute of Population Science (IIPS)-Mumbai and Research Investigator at Tata Institute of Social Science (TISS)-Mumbai.

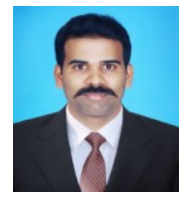

Mr. Raghavendra Nayak currently working as Assistant Professor-Senior Scale. He handles different branches of Economics for both M.Sc and M.Com Courses. He is interested in research in the field of Economics and Banking. He has more than 8 years of teaching experience. His Areas of research Economics and Banking

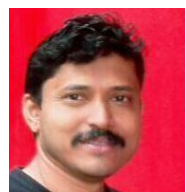

Dr. Nagendra $\mathbf{S}$ has done his Post Graduation and Doctoral Degree in the department of Economics, Mangalore University, and Mangalore. His experience in the teaching includes Managerial Economic, Business Statistics, Quantitative Techniques, Econometrics Financial Management, Strategic Credit Management Banking and Financial Services, Insurance and Risk Management, Merger and Acquisition and Marketing subjects. He has published 04 Books, 02 Scopus Publications, 04 UGC care list Publications, 04 other peer reviewed Publications and total 19 national and international publications. He has reviewed manuscripts for International Journals. At present he is the Chief Advisor of 03 International Journals.

He has attended total 14 Conference and presented papers and organized 15 Guest Talks/Training programs.

$\mathrm{He}$ is the Editorial Board Member of

- Editorial board member of International Journal of Multi Dimensional Research http://www.ijmr.net.in/educational-board.php

- Editorial board member of Journal of Software Project Management and Quality Assurance (Serial Publications) Member of AIMS International

Member of SANDEE

Member of ISTD

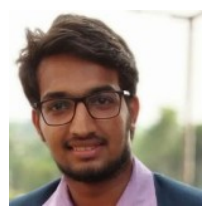

Mr Aswith has done his Post Graduation in the department of Business Administration, Alva's Institute of Engineering \&; Technology, Moodbidri ,affiliated to VTU. At present he is working as Assistant Manager at Kotak Mahindra Bank Limited, Mumbai. He is having the experience of working with export inward remittance team of trade finance department at Kotak Mahindra Bank. $\mathrm{He}$ is having certifications in Business English Communication from Cambridge University and Computer from National Institute of Information Technology.

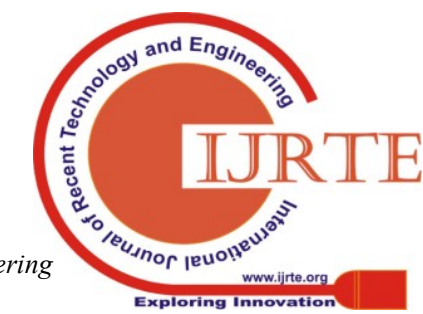

